Viso - Cadernos de estética aplicada Revista eletrônica de estética

ISSN 1981-4062

$N^{0} 22$, jan-jun/2018

http://www.revistaviso.com.br/
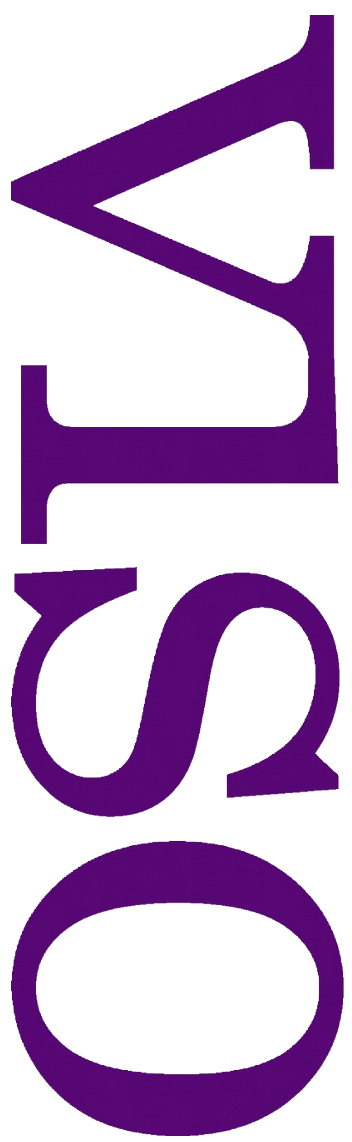

\title{
Quando perco o ânimo e invejo as feras selvagens: o otimismo em Dias felizes \\ Gleydson Ferreira
}




\section{RESUMO}

Quando perco o ânimo e invejo as feras selvagens: o otimismo em Dias felizes

O presente artigo aborda a construção do otimismo em Dias felizes, de Samuel Beckett. Para tanto, debate como o otimismo é configurado, sobretudo em resposta ao pessimismo, resultante da situação alarmante e irremediável em que se encontra Winnie; enterrada em cena durante todo o drama. Evidencia-se, desse modo, como há um recuo subjetivo, geralmente por meio da distração, cujo efeito é a autopreservação. Assim, Winnie recorre à rotina maquinal, às frases otimistas, e ao palavrório incessante, a fim de não sucumbir ao completo descontrole. Todavia, o fracasso revela-se desde o início. Condenada não apenas à repetição incessante das ações, mas também à suspensão da própria morte, Winnie perpetua-se na antessala do aniquilamento total, sendo incapaz de uma mudança significativa, ou mesmo de sustentar a boa disposição por muito tempo.

Palavras-chave: otimismo - Dias felizes - alegoria

\section{ABSTRACT}

When I Lose Heart and Envy the Brute Beast: The Optimism in Happy Days

This paper tackles the creation of optimism in Samuel Beckett's Happy days. In order to do so, we discuss how said optimism is shaped, especially in opposition to the pessimism resulting from the alarming and irreparable circumstances in which Winnie finds herself; buried on stage during the whole extension of the play. Thus, we shed light on a subjective detachment, often by means of distraction and aiming self-preservation. This way Winnie appeals to a mechanical rut, to optimistic phrases and to idle chatter, so as to not give way to utter lack of control. Nevertheless, failure is disclosed from the beginning. Sentenced not only to ceaseless repetition of actions, but also to the suspension of death itself, Winnie perpetuates in the hall of absolute annihilation, as she is unable to achieve significant change, or even to uphold enthusiasm for some time.

Keywords: optimism - Happy Days - allegory 
FERREIRA, G. "Quando perco o ânimo e invejo as feras selvagens: o otimismo em Dias felizes". In: Viso: Cadernos de estética aplicada, v. XII, n. 22 (janjun/2018), pp. 75-90.

DOI: $10.22409 / 1981-4062 / v 22 i / 240$

Aprovado: 19.02.2018. Publicado: 30.06.2018.

(C) 2018 Gleydson Ferreira. Esse documento é distribuído nos termos da licença Creative Commons Atribuição-NãoComercial 4.0 Internacional (CC-BY-NC), que permite, exceto para fins comerciais, copiar e redistribuir o material em qualquer formato ou meio, bem como remixá-lo, transformá-lo ou criar a partir dele, desde que seja dado o devido crédito e indicada a licença sob a qual ele foi originalmente publicado.

Licença: http://creativecommons.org/licenses/by-nc/4.0/deed.pt_BR

Accepted: 19.02.2018. Published: 30.06.2018.

(C) 2018 Gleydson Ferreira. This document is distributed under the terms of a Creative Commons Attribution-NonCommercial 4.0 International license (CC-BY-NC) which allows, except for commercial purposes, to copy and redistribute the material in any medium or format and to remix, transform, and build upon the material, provided the original work is properly cited and states its license.

License: http://creativecommons.org/licenses/by-nc/4.0/ 
Cedo ou tarde, na vida, cada um de nós se dá conta de que a felicidade completa é irrealizável; poucos, porém, atentam para a reflexão oposta: que também é irrealizável a infelicidade completa. Os motivos que se opõem à realização de ambos os estados-limite são da mesma natureza; eles vêm de

nossa condição humana, que é contra qualquer "infinito". Assim, opõe-se a esta realização o insuficiente conhecimento do futuro, chamado de esperança no primeiro caso e de dúvida quanto ao amanhã, no segundo. Assim, opõe-se

a ela a certeza da morte, que fixa um limite a cada alegria, mas também a cada tristeza. Assim, opõem-se as inevitáveis lides materiais que, da mesma

forma como desgastam com o tempo toda a felicidade, desviam a cada

instante a nossa atenção da desgraça que pesa sobre nós tornando a sua percepção fragmentária, e, portanto, suportável.

(Primo Levi)

Sob um sol escaldante, em meio à desolação total, Winnie encontra-se enterrada até a cintura, em uma pequena colina, no centro do palco. Na casa dos cinquenta anos, com seios fartos no amplo decote, braços e ombros desnudos, ela ainda conserva alguma beleza. À sua direita, encoberto pela colina, está Willie. Apesar da luz ofuscante, ambos dormem. Durante uma longa pausa, no descortinar da peça, nada acontece. Até que o toque estridente de uma campainha, que surge fora da cena, marca o fim da pausa e o início da ação, com Winnie acordando, e Willie, ainda oculto para o público, sem qualquer reação. Não demora muito e ela se entrega ao ritual do cotidiano, orando e escovando dentes, embora esteja claramente privada de uma vida normal. A atitude maquinal de Winnie contrasta com a condição aterradora de seu aprisionamento, sem qualquer indício de resistência ou abatimento de sua parte. Assim, a normatividade rotineira da personagem choca-se com o estado absurdo em que se encontra, acirrando o estranhamento inicial ao insinuar a assimilação de uma situação que, a rigor, não poderia ser assimilada. O contrassenso da passividade ante $\mathrm{o}$ inapreensível do soterramento de Winnie está também no seu discurso, que nos surpreende de imediato com a primeira frase: "Mais um dia celestial". 1 Todavia, a disposição favorável da protagonista logo dá mostras de cansaço, e o desespero, antes latente, assume de vez a cena de Dias felizes.

Em pouco tempo, fica claro que o otimismo de Winnie se mantém a duras penas. Para preencher o vazio dos dias, ela preserva uma pantomima elaborada, bem como um palavrório perene, intercalando gestos e palavras ao longo do primeiro ato. Ambos parecem integrar o aparato defensivo de Winnie, de modo que a boa vontade surge como antídoto ao desalento iminente. Com o raio de ação limitado, o gestual da personagem está reduzido a uns poucos objetos que estão ao seu alcance, em uma grande bolsa preta, à sua esquerda, e a uma sombrinha dobrável, visível apenas pelo cabo, à sua direita. Alguns dos movimentos de Winnie dão a impressão de reprodução, como se estivessem traçados de antemão e obedecessem a um roteiro tácito. A gestualidade monótona sugere um desenho antigo, estabelecido a partir de uma toalete rigorosa, aparentemente desnecessária para a protagonista que está padecendo em cena, porém indispensável para a inviolabilidade de seu hábito. Por conseguinte, a 
coreografia de Winnie atesta o controle sobre as pequenas manobras do dia a dia, assegurando tranquilidade a quem pode sucumbir, pelo menor dos sobressaltos, ao completo descontrole.

Discursivamente, Winnie recorre a bordões e a frases feitas, mantendo um contentamento falacioso. Entregue às palavras como forma de distração, por vezes ela deixa escapar algo inconveniente, ou contrário às próprias afirmações. Os refrãos de Winnie funcionam como ritornelos, devolvendo reflexões conscientes ao curso sereno das ideias prontas. Além disso, a protagonista de Dias felizes endereça seu discurso a Willie, em tom dialogal, ignorando a solidão em que de fato se encontra.

Willie, ao contrário de Winnie, goza de liberdade; porém, parece estar seriamente debilitado. Pouco se pode conhecer a respeito de Willie: primeiramente, ele está oculto no palco, fazendo breves aparições parciais, de costas, enquanto lê seu velho jornal; posteriormente, ele será praticamente suprimido de cena. Por mais que Winnie procure estabelecer um diálogo com Willie, ele parece estar desinteressado ou até mesmo impossibilitado de manter uma conversação, permanecendo, na maior parte do tempo, em silêncio. Já quando ele responde a Winnie, dá-lhe respostas breves e equivocadas. Destaca-se não só como a participação de Willie é mínima em quase toda a peça, mas também como ele consegue, por intermédio do discurso de Winnie, figurar como contraponto cênico; se não de forma precária, pelo menos virtualmente. Logo no começo do primeiro ato, a presença de Willie não pode ser notada pelo espectador, sendo então insinuada por Winnie. No segundo ato, quando Winnie não pode mais vê-lo, e sua ausência nos parece definitiva até momentos antes do encerramento, ele continua a ser invocado na fala incessante de sua esposa. Portanto, mesmo que imperceptível, a presença de Willie perdura, no discurso de Winnie, mediada. Com o engodo dialógico, o palavrório solitário de Winnie sugere a companhia efetiva de seu marido, como interlocutor a quem se dirige.

A despeito de toda a boa disposição, Winnie falha. Aos poucos, ela deixa escapar uma amargura condizente com a situação alarmante de enterrada viva. Os lampejos de Winnie surgem entremeados a ações e a afirmações despropositadas, fraturando a superfície frágil de sua tranquilidade. É o que vemos, por exemplo, no começo do primeiro ato, quando Winnie examina sua boca:

(vasculha a bolsa) - nenhum remédio - (tira um pequeno espelho, volta a ficar de frente) - ah, é assim - (examina os dentes no espelho) - coitado do meu Willie (forçando os incisivos superiores com o polegar, voz pouco clara) - minha nossa! (erguendo o lábio superior para observar a gengiva, mesma voz) - tudo bem - (o outro canto, mesma voz) - não piorou nem melhorou - (deposita o espelho) - na mesma - (seca os dedos na grama) — nada de dor - (procura a escova de dentes) quase nada. ${ }^{2}$ 
Durante a inspeção bucal, Winnie não chega a uma conclusão e relativiza suas impressões. Enquanto verifica os dentes, com um espelho de mão, primeiramente ela afirma espantada: "minha nossa!". O tom exclamativo sugere algum tipo de surpresa, aparentemente desagradável. Impressão que logo é desfeita com a observação "tudo bem". A estabilidade emocional parece retomada, de sorte que, nas palavras de Winnie, o estado de sua boca "não piorou nem melhorou". Ainda em consonância com o trecho anterior, a personagem constata: "nada de dor", acrescentando, entretanto, "quase nada". Apesar de banal, a situação demonstra o embaraço de Winnie, que não consegue avançar de maneira unívoca. A reação espontânea, de espanto, é prontamente amortecida com a ideia de permanência, isto é, nem de melhora ou piora significativa. Dentro em pouco, contudo, a instabilidade ressurge, na dor que está ausente, ou ao menos "quase". O contínuo cancelamento dos enunciados assinala um conflito interior, proveniente do choque entre o empenho consciente e a manifestação de sentimentos velados, que se manifestam despercebidamente. No segundo ato, com Winnie quase totalmente tragada pelo palco, o pessimismo torna-se explícito, e seu discurso rasura, desta vez, as afirmativas esperançosas proferidas no primeiro ato.

Percebe-se como as falas da citação acima são intermitentes. Constantemente rasuradas, elas desenvolvem fragmentos de pensamentos. Interrompidos, em geral, de imediato; posto que dolorosos. Mesmo no ápice do desespero, momento em que procura ser franca, Winnie não consegue um raciocínio detido. Escapa-lhe, pois, a reflexão profunda, substituída frequentemente pelas observações superficiais, de propósito anestésico. A brevidade da atenção é essencial, destarte, para a construção do otimismo na peça.

Do início ao fim, em Dias felizes, o pior ainda não aconteceu. Para assegurar certa serenidade, Winnie recorre à trivialidade. Dessa maneira, ela faz um recorte que abarca o presente e o entorno, privilegiando uma visão míope em prejuízo de uma perspectiva ampla, prospectiva de sua aniquilação; assim, de difícil apreensão. Atém-se, portanto, ao imediato, evitando reflexões profundas e panorâmicas, porventura desestabilizadoras, de modo que o otimismo é construído por meio de uma limitação perspectiva.

Com a limitação perspectiva, o otimismo torna-se possível nas situações mais adversas. Não por acaso essa concepção vigora em Cândido, obra essencial para a compreensão do otimismo. Em Cândido ou o otimismo, de Voltaire, o protagonista homônimo sofre uma série de desventuras, mantendo, contudo, uma concepção positiva do mundo. Cândido, descrito como um rapaz de modos gentis, de juízo reto e de espírito simples, vivia no castelo do senhor barão de Thunder-ten-tronckh; apontado, pelo narrador, como seu suposto tio. Tudo, referente ao castelo, é apresentado como o melhor possível. Essa caracterização está relacionada à filosofia de Pangloss, preceptor da casa. De acordo com Pangloss, não existe efeito sem causa, bem como tudo ocorre da melhor maneira possível, já que as coisas não podem ser de outro modo. Assim, os acontecimentos, até mesmo os mais descabidos, encontram suas causas, bem como qualquer situação, por 
mais alarmante que seja, é admitida como a melhor. Daí decorre a ingenuidade de Cândido, que considera o melhor de acordo com o que está ao seu alcance, desconsiderando o que está para além de si mesmo. "Portanto", afirma Plangloss, "aqueles que afirmam que tudo vai bem disseram uma tolice: deviam ter dito que tudo vai da melhor maneira possível". ${ }^{3}$. Por essa concepção, não há um bem-estar absoluto, mas uma condição viável de acordo com as possibilidades dadas. Ou seja, limita-se, dentro do concebível, o que é o melhor, adequando-o perspectivamente a diferentes contextos.

A alternância do que é o melhor possível evidencia-se com a errância de Cândido, de sorte que é preciso adequar-se às situações diversas. Após envolver-se com Cunegundes, filha do barão, Cândido é expulso do castelo. A partir daí, sucedem-se várias desgraças. Todavia, mesmo fora do paraíso terrestre, ele não abandona os preceitos de Pangloss. Amparado pelo anabatista Jacques, depois de ter sido repelido por diversas vezes, e de ter recebido, da esposa de um orador que pregava a caridade, um balde de excrementos na cabeça, exclama Cândido: "Mestre Pangloss bem me dizia que tudo vai da melhor maneira possível neste mundo, pois me sinto infinitamente mais tocado por essa sua extrema generosidade do que pela dureza daquele senhor de manto negro e da senhora sua esposa". ${ }^{4}$ Cândido detém-se no gesto de bondade de Jacques, em detrimento dos infortúnios até então enfrentados, sobretudo daqueles impostos pelo orador e sua esposa. Define-se, portanto, um escopo, cujo foco privilegia um ato de bondade em meio a outros tantos de injúria.

Com isso, há um constante ajuste às condições ora impostas. Tanto que o castelo do barão, considerado, de início, o mais belo e agradável possível, é relativizado capítulos depois, quando há o relato da história da velha. A serviço de Cunegundes, a velha cuida de Cândido, açoitado em Lisboa, após o Terremoto de 1755, na companhia do mestre Pangloss, supostamente enforcado na ocasião; ambos penalizados injustamente a pretexto de um auto de fé. No reencontro dos antigos amantes, realizado com o auxílio da velha, Cândido assassina os dois homens que cortejavam alternadamente Cunegundes. Por conta disso, os três fogem. Durante a evasão, ocorrem novos contratempos, que estimulam a reflexão e a rememoração de fatos infelizes do passado. Infortunada desde a invasão das terras paternas pelos búlgaros, Cunegundes duvida de que a velha possa ter sofrido experiências piores. A decrépita mulher, ao ser interpelada, revela-se, no entanto, vítima de enormes atrocidades, que lhe custaram, inclusive, uma das nádegas, cortada para alimentar uma brigada do exército janízaro, então sitiada pelos russos, em Azov. Nota-se, pois, que o sofrimento da senhora foi maior do que todos os outros apresentados anteriormente. Todavia, a amplitude dessa violência não é medida tão somente pelos atos em si, tampouco pelo modo como se sucederam, de modo que se deve considerar, da mesma forma, a posição social da vítima. Por isso, é importante, nesse trecho, não só a narrativa do destino desventuroso, mas também da ventura que o precede. A respeito de sua origem, relata a velha: 
Nem sempre tive os olhos encarniçados e rodeados de vermelho; meu nariz nem sempre chegou até o queixo, e nem sempre fui criada. Sou filha do papa Urbano X e da princesa de Palestrina. Fui criada até os catorze anos num palácio tal que todos os castelos de seus barões não teriam servido nem de estrebaria; e um dos meus vestidos valia mais que todos os luxos da Westfália. ${ }^{5}$

Descrita a infância da velha, é preciso rever a escala do melhor castelo possível. Pois o castelo do barão, onde cresceu o casal, já não é o melhor quando comparado ao do papa. O mesmo acontece com as atrocidades sofridas por Cândido e Cunegundes. Embora eles tenham padecido bastante, essa proporção tem de ser revista com o destino, ainda pior, da idosa. Ademais, nessa porção, deve-se considerar não só o sofrimento, mas também a quem ele é infligido. Pois tanto maior será o infortúnio quanto melhor for a fortuna inicial.

Semelhante princípio está em Dias felizes. A percepção de Winnie presa a um mundo pós-apocalíptico modifica-se à medida que ficamos cientes do seu passado corriqueiro, ou seja, a excepcionalidade do estado atual é acentuada pelo contraste com a normalidade que a precedeu. Em Dias felizes convergem estágios distintos do mesmo mundo: a princípio, o comum, rememorado e mantido na toalete de Winnie; posteriormente, outro, absurdo, vivenciado em cena com objetos que se autorregeneram e com um sol que se mantém mesmo à noite. Porém, diferentemente de Cândido, Winnie não se adapta à brusca mudança. Daí o seu insucesso. Por mais que tente se ajustar, ela fracassa. Aprofundado de vez seu corpo, sobra-lhe a cabeça, mas sem que ela consiga adequar a perspectiva otimista ao segundo ato. Com isso, Winnie atinge um estágio de sofrimento inassimilável. Descontrola-se então, sucumbindo ao abatimento.

No Cândido, os acontecimentos sucedem-se vertiginosamente rumo à constante piora; até que se estabilizam, porém. Por fim, Cândido casa-se com Cunegundes, fixando-se, com os amigos, em uma pequena granja de Constantinopla, onde todos dedicam-se ao trabalho árduo - cuja execução torna-se uma espécie de redenção filosófica. A progressão das ações, embora catastrófica, encontra um desfecho. A esse propósito, Italo Calvino, em "Cândido ou a velocidade", observou que "se o carrossel de desastres pode ser contemplado com um sorriso à flor dos lábios é porque a vida é rápida e limitada". ${ }^{6} \mathrm{O}$ empreendimento otimista depende tanto do distanciamento, daquele que, a um só tempo, compõe e contempla o carrossel de desastres, quanto da velocidade e limitação da vida. Assim sendo, o carrossel não parece uma imagem adequada ao Cândido, cujo avanço e ponto de chegada nada têm de circulares.

Em compensação, o movimento circular caracteriza Dias felizes. Winnie retoma falas já ditas, repetindo-se indefinidamente. A suspensão do tempo e a paralisia do corpo submetem-na à repetição estéril. Na duração do drama as ações cênicas encontram-se avançadas desde o início e inconclusas ao término. Winnie perdura à beira da morte que nunca se concretiza. Ademais, o ritmo do primeiro ato, o mais longo dos dois, é 
cadenciado, fazendo com que as falas e as ações se delonguem. É possível notar a dilação do tempo em Dias felizes mesmo nas ações mais banais:

\begin{abstract}
WINNIE
Totalmente garantida... (Willie para de abanar)... puras e autênticas... (Pausa. WILLIE volta a abanar. WINNIE olha mais de perto, lê.) Totalmente garantida... (WILLIE para de abanar) ... puras e autênticas... (Pausa. WILLIE volta a abanar. WINNIE deposita a lente [de aumento] e a escova, tira o lenço escondido no decote, tira os óculos, limpa-os, recoloca os óculos, procura a lente, pega e limpa a lente, deposita a lente, procura a escova, pega a escova, esfrega o cabo, deposita a escova, devolve o lenço para o decote, procura a lente, pega a lente, procura a escova, pega a escova e examina o cabo com a lente.) Totalmente garantida... (WILLIE para de abanar)... puras e autênticas (Pausa. WILLIE volta a abanar) ... cerdas... (WILLIE para de abanar, pausa)... cerdas de capão. (Pausa. WINNIE deposita o espelho [sic] e a escova, o jornal desaparece, WINNIE tira os óculos, deposita-os, olha para a frente.) Cerdas de capão. (Pausa). Isso é que acho maravilhoso, que não passe um dia sequer — (sorriso) — ah, o velho estilo! - (desfaz o sorriso) - quase nenhum, sem algum acréscimo ao nosso saber, por pequeno que seja, o acréscimo, quero dizer, ainda que não nos esforcemos muito. ${ }^{7}$
\end{abstract}

De todo prosaico, o trecho acima apresenta, entretanto, uma elaborada coreografia. Nota-se como há indicações de pausas constantes, bem como de movimentos tediosos. Tudo isso contribui para que o desenvolvimento cênico seja atravancado e lento; além de repetitivo. Com isso, a velocidade e a finitude, responsáveis pelo sucesso do otimismo de acordo com Calvino, são negadas a Winnie, que está condenada ao vagaroso looping dos dias tórridos. Ademais, se o trabalho é a redenção em Cândido, em Dias felizes não passa de subterfúgio para fugir à estranha realidade. A pretexto de alargar o conhecimento, Winnie ocupa-se em desvendar o que está escrito em sua escova de dentes. No entanto, pelo despropósito da situação em que está inserido, esse esforço não passa de mera distração. Isto é, a autoimposição de uma alienação obtida pelo trabalho, comparável àquela estampada no portal de entrada de Auschwitz, o mais célebre dos Campos Nazistas, onde se lê que "o trabalho liberta".

A velocidade dos acontecimentos parece modificar consigo a "curva da sensibilidade humana à dor". ${ }^{8}$ Essa expressão, elaborada por Friedrich Nietzsche na Genealogia da moral, assinala uma relativização da tolerância à dor no decorrer do tempo. Para Nietzsche, o homem moderno tolera menos a dor do que seus antepassados. Dessa maneira, a dor física, lancinante, teria sido trocada por outras formas de sofrimento, mais sutis e sublimadas. Contudo, essa observação considera diferentes períodos históricos, não a mudança repentina da sensibilidade à dor, bem como desconsidera retrocessos civilizatórios, capazes de reinstaurar a violência de estágios pregressos da humanidade. A mudança acelerada da sensibilidade humana à dor pode ocorrer com rupturas bruscas no decurso de uma vida, levando um mesmo indivíduo a experimentar escalas distintas de sofrimento.

Por si só, a boa aparência de Winnie destoa do mundo arruinado em que se encontra. Há algum tempo castigada pelo sol ininterrupto, alimentando-se mal, é difícil conceber 
que ela esteja conservada, um pouco acima do peso, e com seios fartos. Também é inusitado que ela ainda ostente um colar de pérolas, além de vários outros objetos supérfluos, guardados a tiracolo na grande bolsa. O estado físico relativamente favorável da protagonista e os objetos presentes em cena remetem a um passado diferente, presente apenas residualmente. Decerto os objetos de Winnie são o vínculo mais concreto com uma vida pretérita. De acordo com Ruby Cohn:

In her bag Winnie finds tooth-brush, toothpaste, mirror, spectables, medicine-bottle, lipstick, hat, magnifying glass, comb and brush, music-box, nail file, revolver. Except perhaps for the last of these, the props are those of any middle-class, middle-age woman. Winnie uses them to endure until the bell for sleep. And so do we. Thus we camouflage our dying, but Winnie cannot die, and she lives her present, noting its several facets, of which the most vital is Willie. ${ }^{9}$

Com posses e aparência típicas de uma mulher da classe média, Winnie encontra-se contextualmente deslocada. Os pontos de contato entre a nossa realidade e a da personagem são evidentes. A ponto de permitirem que Cohn trace um paralelo, assinalando como os objetos preenchem a rotina de Winnie de maneira análoga ao modo como preenchem a nossa; sobretudo, como eles camuflam a morte dela tanto quanto a nossa. Todavia, se é possível reconhecer as similitudes do passado de Winnie com o presente, o mesmo não pode ser feito em relação à atualidade cênica da peça. Em Dias felizes - assim como em outros trabalhos de Samuel Beckett —, não há referências a locais ou a tempos históricos específicos. Ainda assim, os objetos e a aparência da protagonista asseguram que ela pertenceu ao mundo moderno, tal como o conhecemos, mas que, em algum momento, foi deslocada para uma realidade adversa; ou ainda que esse mundo foi drasticamente transformado, remanescendo apenas metonimicamente. Seja qualquer um deles, fato é que Winnie experimentou uma drástica mudança. Se antes estava inserida em um cotidiano de bailes e de pedidos de casamento, agora se encontra em uma versão depravada do mundo. Com isso, evidencia-se uma ruptura com um cotidiano usual, ocorrida em decorrência de algum acontecimento indefinível e irremediável. Um desastre forte e célere o bastante para modificar definitivamente o dia a dia de Winnie. Assim como célere o bastante a ponto de preservar indícios de uma vida pretérita, como evidenciam os objetos cênicos, situada em um passado não muito longínquo.

A indeterminação temporal e espacial de Dias felizes repele referências históricas imediatas. Com sete versões, a peça sofreu uma série de modificações, preservando, todavia, a ideia primária de uma mulher enterrada, em um lugar inóspito, acompanhada de um marido emudecido. De acordo com Fábio de Souza Andrade, "o sentido das revisões é o de cultivar as potenciais ambiguidades, apagando referências a processos históricos específicos, valorizando o que no vago, na alusão que não nomeia diretamente, cede espaço à incerteza de significados ou à disputa de sentidos conflitantes"..$^{10} \mathrm{O}$ cultivo das ambiguidades potenciais, no método de Samuel Beckett, tem por consequência uma dramaturgia alegórica. 
Sem referências explícitas, o drama de Samuel Beckett não abandona a representação histórica. Muito pelo contrário, ele comporta uma diversidade de leituras ao tornar-se uma configuração abstraída da realidade imediata, possibilitando diferentes problematizações a partir de um cosmos fechado, que coexiste com uma variedade de processos históricos e sociais. Nesse sentido, pode-se afirmar que as considerações sobre a arte monadológica de Walter Benjamin, em Origem do drama trágico alemão, aplicam-se à dramaturgia beckettiana. Afirma Benjamin:

A ideia é um mônada. O ser que nela penetra com a sua pré e pós-história mostra, oculta na sua própria, a figura abreviada e ensombrada do restante mundo das ideias, tal como nas mônadas do Discurso sobre a metafísica, de 1686: em cada uma delas estão indistintamente todas as demais. A ideia é uma mônada - nela repousa, preestabelecida, a representação dos fenômenos como sua representação objetiva. E assim o mundo real poderia ser visto como problema, no sentido de que nos pede para penetrarmos de tal modo em tudo o que é real que daí resultasse uma interpretação objetiva do mundo. [...] A ideia é uma mônada — isso significa, em suma, que cada ideia contém a imagem do mundo. A tarefa imposta à sua representação é nada mais nada menos que a do esboço dessa imagem abreviada do mundo. ${ }^{11}$

Mesmo que abstraída, a obra de arte, assim como a mônada, comporta em si a figura abreviada do restante do mundo. Para Benjamin, o mundo real poderia ser visto como um problema representacional, cuja demanda seria de um relato integral e objetivo. Daí a impossibilidade de abarcar toda a objetividade em uma única configuração. Já a forma reduzida do mundo, monadológica, contém uma síntese do mundo. Ou seja, uma condensação que reflete o mundo em sua essencialidade, ainda que não se detenha específica e integralmente em fenômenos da realidade.

Peter Szondi abordou particularmente a representação da realidade quando analisou o drama social. O dramaturgo social deve inventar ações que ilustrem determinadas condições históricas a fim de tratar dos ditames econômicos e sociais que sujeitam os indivíduos. Todavia, a temática social torna-se secundária, de modo que o drama não encena a realidade em si mesma, mas a representa. Destarte, segundo Szondi,

a ação representativa não é uma ação dramática: o fato no drama, enquanto absoluto, não aponta para nada além dele. Mesmo na tragédia filosófica de um Kleist ou de um Hebbel a fábula não possui uma função demonstrativa; ela é "significante" não porque alude, para além de si mesma, às propriedades do mundo, tal como ensina a metafísica do poeta, mas porque concentra o olhar para dentro de si mesma, para as próprias profundezas metafísicas. O que de modo algum restringe sua capacidade de enunciação; ao contrário, o mundo do drama é capaz de tomar o lugar do próprio mundo graças justamente ao seu caráter absoluto. Desse modo, a relação entre significante e significado baseia-se, quando muito, no princípio simbólico da coincidência do microcosmo e do macrocosmo, mas não no princípio da pars pro toto. ${ }^{12}$

Por conseguinte, nem mesmo o drama social, que versa sobre aspectos da realidade, é uma representação da objetividade. Antes disso, ele aponta para suas próprias profundezas metafísicas. A relação entre drama e história - ou seja, entre significado e 
significante -, ocorre pela coincidência do microcosmo e do macrocosmo. Em outras palavras, a representação microcósmica do drama por vezes afina-se com o macrocosmo que a envolve, possibilitando, então, uma associação mediada.

O mundo pode, segundo Szondi, ser substituído por outro, representacional. Dado que absoluto, o drama é uma imagem apartada de seu próprio anteparo. Há, no entanto, uma variação do distanciamento que confere ao drama um caráter simbólico ou alegórico. $\mathrm{O}$ primeiro, simbólico, ocorre quando é possível relacionar o drama a contextos mais específicos, delimitados pela sua própria configuração. Já o segundo, alegórico, resulta de uma profusão contextual, cuja abstração permite a transferência de significação, conforme é relacionada, interpretativamente, a variados fenômenos históricos e sociais.

O drama Dias felizes é essencialmente alegórico. Ao apresentar como cenário um lugar devastado, seu espaço parece remeter à destruição provocada pela Segunda Guerra Mundial - encerrada, àquela época, há menos de duas décadas. Some-se a isso o fato de Samuel Beckett ter sido europeu, de ter residido na França ocupada pelos nazistas e de ter tomado parte na resistência. Indícios que aparentemente naturalizariam o meio arrasado como resultado dos conflitos de então. A despeito das evidências imediatas, a indeterminação espacial da peça permite a Theodor Adorno, na Teoria estética, comparar a colina de areia que prende Winnie às formações desérticas do Oeste americano ${ }^{13}$; deslocando, assim, a representação cenográfica para um espaço distante daquele em que a peça foi concebida. Todavia, se é lícita uma comparação como a de Adorno, seria impossível asseverá-la como definitiva. Porque se a alegoria permite, por um lado, o deslocamento contextual, ela inibe, por outro, uma referência definitiva.

Por essa via, a situação em que se perpetua Winnie, após uma violenta mudança, alegoriza alguns aspectos vivenciados pelos judeus durante o Holocausto. Em É isto um homem?, Primo Levi descreveu uma situação comparável à de Winnie. Deportado para Auschwitz, em 1944, Levi é transposto da civilização para a barbárie do campo de concentração nazista. O mundo, repentinamente tornado estranho, tem de ser por ele assimilado. Todavia, por mais que a nova condição esteja incorporada, não há como se livrar da normalidade precedente, então rememorada e mantida em atos cotidianos. De fato, o campo parece uma versão degenerada da sociedade, com chefes e subalternos, com um comércio vigente, e com raras, mas possíveis, promoções trabalhistas. A exemplo do próprio Levi, promovido de trabalhador braçal a químico, cargo que se enquadra na sua área de formação acadêmica. De todo modo, ocorre a necessidade súbita de se adaptar a novas formas de violência, sem a mediação de um estado de direito. No confinamento, confronta-se a transformação dos processos judiciais em execuções sumárias: aleatórias e praticadas a esmo. Por conseguinte, impõe-se, com o revés do nazismo, a necessidade premente de aclimar-se a condições incomuns de sobrevivência, cujo sucesso depende da resposta à nova curva da sensibilidade à dor. 
De início, Levi encontra dificuldades em adequar-se. Após uma semana de confinamento, descuida-se de sua higiene, sendo repreendido, então, por Steinlauf. Para Steinlauf, ex-sargento do exército austro-húngaro, Cruz de Ferro da Primeira Guerra Mundial, a manutenção da higiene pessoal transcende o cuidado com a saúde e

justamente porque o Campo é uma grande engrenagem para nos transformar em animais, não devemos nos transformar em animais; até num lugar como este, pode-se sobreviver, para relatar a verdade, para dar nosso depoimento; e, para viver, é essencial esforçar-nos para salvar ao menos a estrutura, a forma da civilização. Sim, somos escravos, despojados de qualquer direito, expostos a qualquer injúria, destinados a uma morte quase certa, mas ainda nos resta uma opção. Devemos nos esforçar por defendêla a todo custo, justamente porque é a última: a opção de recusar nosso consentimento. Portanto, devemos nos lavar, sim; ainda que sem sabão, com essa água suja e usando o casaco como toalha. Devemos engraxar os sapatos, não porque assim reza o regulamento, e sim por dignidade e alinho. Devemos marchar eretos, sem arrastar os pés, não em homenagem à disciplina prussiana, e sim para continuarmos vivos, para não começarmos a morrer. ${ }^{14}$

De maneira análoga a Dias felizes, a toalete, embora precária, é para Steinlauf um modo de resistência. Submetido à servidão, e despojado de direitos, recusa-se, contudo, a entregar-se de todo ao campo. Ao negar seu consentimento, recua subjetivamente a fim de resguardar em si a essência da civilidade. Atendo-se aos detalhes ele procura contrapor-se a uma estrutura maior. Steinlauf acredita que sua atitude é responsável até mesmo pela sua sobrevivência. Logo, a rotina herdada de outro contexto é mantida como forma de distanciamento, um modo de deslocar a atenção para propósitos diversos daqueles impostos pelos alemães.

Tempos depois, praticamente adaptado, Levi ocupa-se mais com o cotidiano de Auschwitz do que com assuntos do passado. A inserção no campo, porém, não é fácil. Enquanto se ambienta, instaura-se o medo de que, uma vez assimilado, não seja mais compreendido fora dali. Pois ele não só receia uma incompreensão linguística propriamente dita, mas também a incredulidade sobre a existência do campo; ademais, tem pesadelos sobre a impossibilidade de comunicar os absurdos ali vivenciados. Mesmo com todo o temor, concentra-se em sobreviver. Com o relativo estreitamento de foco, ele consegue, inclusive, experimentar momentos de otimismo e de alento. De acordo com Levi:

Sorte que hoje não há vento. É estranho: de alguma maneira, sempre tem-se [sic] a impressão de ter sorte: de que alguma circunstância, ainda que insignificante, nos segure à beira do desespero, nos permita viver. Chove, mas não está nevando. Ou, chove e venta, mas a gente sabe que à noite nos toca o suplemento de sopa e então, hoje também, encontra-se a força para chegar à noite. Ou ainda: chove, venta, a fome é a de sempre; então a gente pensa que, se precisasse mesmo, se já não tivesse nada em seu coração a não ser sofrimento e tédio (como acontece, às vezes, quando parece mesmo que chegamos ao fundo) ...bem, ainda pensamos que, querendo, em qualquer momento, podemos tocar a cerca eletrificada ou jogar-nos debaixo de um trem em manobras, e então pararia de chover. ${ }^{15}$ 
Destaca-se, aqui, como o otimismo se prende a considerações imediatas, em detrimento das amplas. Por um breve momento, esquece-se da condição de preso em um campo de extermínio para prestar atenção ao ordinário, ou seja, ao dia sem vento ou sem neve, ou à sopa da noite. Levi mostra-se ciente de como há uma adequação do sujeito às adversidades: para cada nova complicação, um ajuste perspectivo. Assim, ocorre uma mudança subjetiva constante, de modo a suportar as situações impostas. Samuel Beckett notou um movimento parecido, ao analisar o romance Em busca do tempo perdido, em Proust. Para Beckett, há uma esfoliação perpétua da personalidade, que se dá por meio do hábito. Conforme assinalado por Beckett, "o Hábito, então, é um termo genérico para os incontáveis compromissos travados entre os incontáveis sujeitos que constituem o indivíduo e seus incontáveis objetos correspondentes". ${ }^{16}$

Todavia, o otimismo tem fôlego curto. Depois de afirmar que se tem sempre a impressão de ter sorte, Levi termina por manifestar o contrário, ou por considerar que a sorte é poder optar, caso queira, pela própria morte. Mesmo com a perspectiva positiva, acusase, por fim, o pessimismo latente. Não se consegue, dessa maneira, uma sustentação do propósito otimista frente ao panorama aterrador. Donde há o cancelamento de enunciados, ou a relativização de ideias. A esse propósito, no capítulo "Um dia bom", ao narrar a saída da fábrica para trabalhar ao ar livre, relata Levi: "Hoje é um dia bom. Olhamos ao redor, como cegos que recuperam a visão, e nos entreolhamos. Nunca nos víramos no sol! Alguém sorri. Se não fosse pela fome...." ${ }^{17}$ Nesse trecho, a consideração otimista é, dali a pouco, revista; sendo condicionada, então, pela fome, que a atrapalha.

O mesmo acontece com Winnie. Embora ela esteja entretida com os afazeres rotineiros, dissimulando seu bem-estar, descontrola-se. Nessas situações, a percepção imediata é abandonada, insurgindo a ampla, cujo vislumbre é o da morte irrefreável. Tanto em É isto um homem? quanto em Dias felizes procura-se suspender, mesmo que temporariamente, a percepção do extermínio iminente, ofuscando, desse modo, a consciência de se perdurar com a morte adiada. Por isso, a possibilidade de se antecipar o fim da vida é um consolo em ambos os casos. Pondera Winnie:

E se, por razões obscuras, nenhum esforço a mais for possível, basta fechar os olhos (fecha os olhos) - e esperar que venha o dia - (abre os olhos) - o dia feliz que virá, em que toda carne derreterá a tantos graus e a noite da lua durará tantas centenas de horas. (Pausa) É o que me consola muito, quando perco o ânimo e invejo as feras selvagens. ${ }^{18}$

Inesperadamente as reflexões transitam da banalidade à hipótese de uma morte proposital. A princípio, Winnie faz considerações sem importância, acerca de como o acréscimo de novos conhecimentos é maravilhoso. Depois, assevera ser um alívio a possibilidade de deixar-se morrer. Porém, o suicídio não parece ser uma possibilidade concreta nesse caso. Pois, mesmo com um revólver ao alcance das mãos, Winnie prefere o adiamento de uma resolução definitiva; assim, aguardar que o mundo se aqueça até o ponto de derreter, enfim, sua carne. 
Ciente da morte inescapável, Winnie delonga-se. Embora consiga vez ou outra alguma distração, ela precisa lidar com o lapso que a separa de sua morte. Além da similitude com Levi, o estado psicológico em que se encontra Winnie coincide, em grande medida, também com o de outros judeus, vítimas do Holocausto, como se observa no filme Shoah ${ }^{19}$, lançado em 1985 por Claude Lanzmann. No documentário, o alemão Franz Suchomel, responsável por manipular os transportes dos judeus no Campo de Treblinka, de 1942 a 1943, afirma que quando os trens cessavam, os "judeus de trabalho" ficavam apreensivos com a possibilidade do próprio extermínio, já que perdiam sua função de mão de obra. Nessas ocasiões, em lugar da morte imediata (na câmara de gás ou por fuzilamento), bem como para evitar revoltas, a ração era simplesmente racionada. Assim, eles eram deixados para morrer de inanição, ou em decorrência de alguma epidemia: em geral por uma espécie de tifo, segundo o próprio nazista. Ainda de acordo com Suchomel, os judeus, submetidos a tão severas condições, por um prazo indefinido, consideravam-se "cadáveres adiados". Sem ocupação, e fracos demais para motins, os judeus empregados nos campos sobreviviam como mortos encomendados, à espera da morte postergada. Havia, portanto, uma espera em que pouco ou nada podia ser feito para mudar o funesto destino, assim como pôde ser visto de maneira análoga em Dias felizes.

A suspensão das ações não se restringe apenas à morte em Dias felizes. Com Winnie presa ao palco, e com a inatividade de Willie, quase nada acontece na superfície cênica. O soterramento de Winnie, por certo o acontecimento central de todo o drama, está bem adiantado logo no início do primeiro ato, e não será visto, em suas últimas consequências, ao término do segundo. Assim, a peça abrange o meio de um processo, que não será esclarecido em suas causas, tampouco alcançará seu curso definitivo em cena. A caminho do inevitável, o presente de Winnie prossegue como a espera pelo pior, que, independentemente de cada novo momento, está sempre por vir. Com efeito, as ações de Winnie não produzem nenhuma mudança significativa, nem revelam as causas do estranho atolamento.

Ainda assim, ruma-se para o pior em Dias felizes. O otimismo, simulado no primeiro ato, mostra-se impraticável no segundo. Com Winnie então encoberta até o pescoço, tornase difícil um afastamento, ou mesmo uma perspectiva restrita, da catástrofe agravada no entreato. Ela é levada ao cancelamento do otimismo precedente, num trecho cênico acelerado; sobretudo em comparação ao outro, inicial. Nesse caso, se o empenho otimista depende do distanciamento e da consciência da finitude, Winnie não consegue mais se distanciar da iminência da morte: está entregue, enfim, ao desespero. Porém, com uma estrutura circular, a boa disposição da protagonista acena no encerramento, ao ser retomada por meio de uma canção cujo tema é o amor endereçado a Willie, o marido indiferente, então ao pé da colina em que se encontra Winnie, sem que consiga, no entanto, alcançá-la. 


\section{* Gleydson Silva Ferreira é mestre em letras pela UFOP.}

${ }^{1}$ BECKETT, S. Dias felizes. Tradução de Fábio de Souza Andrade. São Paulo: Cosac \& Naify, 2010, p. 30.

2 Ibidem.

${ }^{3}$ VOLTAIRE. Cândido ou o otimismo. Tradução de Samuel Titan Jr. São Paulo: Editora 34, 2013, p. 19.

${ }^{4}$ Ibidem, p. 29.

${ }^{5}$ Ibidem, p. 63.

${ }^{6}$ CALVINO, I. "Cândido ou a velocidade". In: VOLTAIRE. Cândido, ou o otimismo. Tradução de Samuel Titan Jr. São Paulo: Editora 34, 2013, p. 192.

${ }^{7}$ BECKETT, S. Op. cit., p. 35.

${ }^{8}$ NIETZSCHE, F. Genealogia da moral: uma polêmica. Tradução Paulo César de Souza. São Paulo: Companhia das Letras, 1998, p. 57.

${ }^{9} \mathrm{COHN}, \mathrm{R}$. Back to Beckett. Princeton: Princeton University Press, 1973, p. 179.

${ }^{10}$ ANDRADE, F. de S. "A felicidade desidratada". In: BECKETT, S. Dias felizes. Tradução de Fábio de Souza Andrade. São Paulo: Cosac \& Naify, 2010, p. 10.

${ }^{11}$ BENJAMIN, W. Origem do drama trágico alemão. Tradução de João Barrento. Belo Horizonte: Autêntica, 2011, pp. 36-37.

${ }^{12}$ SZONDI, P. Ensaio sobre o trágico. Tradução de Pedro Süssekind. Rio de Janeiro: Jorge Zahar, 2004, pp. 76-77.

${ }^{13}$ ADORNO, T. W. Teoria estética. Tradução de Artur Mourão. Lisboa: Edições 70, 1970, p. 99.

${ }^{14}$ LEVI, P. É isto um homem?. Tradução de Luigi Del Re. Rio de Janeiro: Rocco, 1988, p. 39.

${ }^{15}$ Ibidem, p. 133.

${ }^{16}$ BECKETT, S. Proust. Tradução de Arthur Nestrovski. São Paulo: Cosac \& Naify, 2003, p.17-18.

${ }^{17}$ LEVI, P. Op. cit,, p. 73.

${ }^{18}$ BECKETT, S. Dias felizes. Op. cit., p. 35.

${ }^{19}$ Shoah. Direção: Claude Lanzmann. França, 1985. 543 min. 